Article

\title{
Competing Institutional Logics and Paradoxical Universalism: School-to-Work Transitions of Disabled Youth in Switzerland and the United States
}

\author{
Christoph Tschanz ${ }^{1, *}$ and Justin J. W. Powell ${ }^{2}$ \\ ${ }^{1}$ Department of Social Work, Social Policy and Global Development, Faculty of Humanities, University of Fribourg, \\ CH-1700 Fribourg, Switzerland; E-Mail: christoph.tschanz@unifr.ch \\ 2 Institute of Education \& Society, University of Luxembourg, L-4366 Esch-sur-Alzette, Luxembourg; \\ E-Mail: justin.powell@uni.lu \\ * Corresponding author
}

Submitted: 4 October 2019 | Accepted: 27 January 2020 | Published: 18 March 2020

\begin{abstract}
Disablement is a complex social phenomenon in contemporary societies, reflected in disability policies oriented towards contrasting paradigms. Fraught with ambivalence, disability raises dilemmas of classification and targeted supports. Paradoxical universalism emphasizes that to achieve universality requires recognizing individual dis/abilities and particular contextual conditions and barriers that disable. Myriad aspects of educational and disability policies challenge both conceptualization and realization of universal policies, such as compulsory schooling, with widespread exclusion or segregation prevalent. Resulting tensions between providing support and ubiquitous stigmatization and separation are endemic, and particularly evident during life course transitions that imply shifting memberships in institutions and organizations. Particularly visible among disabled youth, school-to-work transitions are fundamentally challenged by contrasting policies, institutional logics, and institutionalized organizations. Analyzing institutional logics facilitates understanding of the lack of coordination that hinders successful transitions. Examining such challenges in the United States and Switzerland, we compare their labor markets and federal governance structures and contrasting education, welfare, and employment systems. Whereas lacking inter-institutional coordination negatively impacts disabled young adults in the United States, Switzerland's robust vocational education and training system, while not a panacea, does provide more coordinated support during school-to-work transitions. These two countries provide relevant cases to examine ambivalence and contestation around the human right to inclusive education as well as the universality of the right (not) to work.
\end{abstract}

\section{Keywords}

comparative education; comparative social policy; disability; disability policy; education; educational policy; institutions; institutional logics; organizations; school-to-work transitions

Issue

This article is part of the issue "'Universalism' or 'Universalisms' in Social Policies?” edited by Monica Budowski (University of Fribourg, Switzerland) and Daniel Künzler (University of Fribourg, Switzerland).

(C) 2020 by the authors; licensee Cogitatio (Lisbon, Portugal). This article is licensed under a Creative Commons Attribution 4.0 International License (CC BY).

\section{Introduction: Situating Disablement in School-to-Work Transitions}

Compulsory schooling during childhood and youth, and commodified work during adulthood, have come to constitute the core principles of a "normal" life course in most contemporary societies yet cannot be taken for granted in the case of disabled people. If educated citizenry are the foundation of a democracy, they also represent the basis of a nation's economy because skill formation is crucial not only for formulating political values but also for working in complex organizations. Compulsory schooling laws were originally enacted to socialize national citizens and to ensure the preparation of future 
workers (Heidenheimer, 1997). By offering free public education and making it compulsory, democratic nationstates acknowledge the intimate relationship between education and citizenship (Marshall, 1950/1992, p. 16). At the nexus of industrializing nation-states, forceful social movements and growing citizenship rights, mass schooling arose with the cultural ideologies of the nationstate (e.g., Boli, Ramirez, \& Meyer, 1985). Global ideals are more powerful than ever in "schooled societies" (Baker, 2014) in which schooling increasingly determines individual identities and life chances.

Although special education programs have fostered integration into education systems and provide supports to access curricular contents, children and youth with recognized impairments or special educational needs (SEN) are routinely stigmatized and separated or segregated from their peers - this constituting much of their disablement (Powell, 2011/2016). Their school-to-work transitions are especially challenging, as comparisons of transition outcomes from the United States (Haber et al., 2016) and Europe (Halvorsen \& Hvinden, 2018) emphasize. The focus on transitions between schooling and vocational education and training (VET) and labor markets is driven by the importance of success in mastering these transitions for life chances. The factors bearing on transitions are complex. Learning opportunities provided within environments of schooling, VET programs, and firms foster development. The information and support youth receive from state programs and within their social networks facilitate transitions, even as gatekeepers' recruitment behavior adds bias in the face of "institutional discrimination" (Gomolla \& Radtke, 2002). Individual motivation, competencies, and decision-making are crucial (see Ludwig-Mayerhofer et al., 2019).

At macro and meso levels, institutions and organizations that constitute the adjoining spheres of education and work are central to constructing disability categories. These determine who is eligible for targeted support and services-and impact which youth become (classified as) disabled. Organizations are embedded in contrasting "institutional logics" (Aldrich \& Ruef, 2006; Friedland \& Alford, 1991; Thornton, Ocasio, \& Lounsbury, 2012), with individuals needing to adapt to these sets of values, ideals, and practices that provide meaning to daily activities. Logics and the challenges of inter-institutional coordination, we argue, are particularly salient as individuals (attempt to) transition from school to work, as these institutional logics demand of individuals different kinds of performances. The supports provided also differ markedly. In educational policies, tensions between the need for the provision of learning opportunities and wellbeing in schooling, and the ever-present risk of stigmatization via "negative classification" (Neckel \& Sutterlüty, 2005) are endemic. Receiving specific supports and special services may be viewed positively or negatively, especially when an official classification is required, described as the "resource-labeling-dilemma" (Füssel \& Kretschmann, 1993). Welfare state institutions structure the ambiguous and ambivalent disability classification systems and their categories. Access to a need-based distribution system as a substitute for a work-based distribution system involves institutions favoring official medical or legal knowledge and standards to classify impairments and (chronic) illnesses, and consequently people, representing a "distributive dilemma" (Stone, 1984) in policymaking.

At the intersection of schooling, VET, and work, we argue, the contrasting, even competing, logics guiding education and work institutions and organizations become starkly evident. Neither stakeholders nor individuals seem adept at negotiating or mastering contradictory institutionalized ideas, norms, and regulations in these major institutions that shape so much of our contemporary life courses. Thus, we here analyze these competing institutional logics and uncover the paradoxical universalism in disability policies impacting school-to-work transitions, exemplified by the contrasting cases of the United States and Switzerland.

Facilitating our comparative analysis, these two country cases have federal governance structures and liberal labor markets but contrasting education, welfare, and employment systems. Our process of social inquiry follows the case study method (Ragin, 1992). We intertwine our in-depth knowledge, gained through numerous prior research projects, of the cultures and structures of US and Swiss educational, welfare, and employment institutional arrangements (e.g., Powell, 2011/2016; Tschanz, 2017). We link ideas and evidence in a collaborative process and present the characteristics of these country cases, aiming for meaningful "theoretically structured descriptions of the empirical world" (Ragin, 1992, p. 225). We examine educational and social policies and their underlying characteristics of universalism versus selectivism with regard to the construction of "kinds" of persons via official categories, their provisions and institutionalized organizations, and outcomes. Furthermore, we discuss the contrasting macro regimes and institutional logics driving these (sub)national education and social systems and challenges faced within two federal countries.

\section{Theoretical Framework}

\subsection{Paradoxical Universalism and Dilemmas of Disability Classification}

Disability policies in education and employment as well as in social protection are characterized by paradoxical universalism and dilemmas resulting from disability classification and categories that often stigmatize individuals and groups even as they benefit from targeted policies and programs. Universalism is a polysemic concept having contrasting meanings within the academic field of social policy research (Stefánsson, 2012). Indeed, recent research proposes to acknowledge and investigate "varieties of universalism" (Anttonen \& Sipilä, 2014, p. 3) 
or to use the paradoxical term "universalisms" (Künzler \& Nollert, 2017, p. 9). When applied, the ambiguity of the term universalism manifests itself, particularly, we argue, when analyzing classifications and categories of impairment, disability, and special (educational) needs which are themselves contested and dynamic concepts when applied to individuals because of the environmentally contingent nature of disablement as a social and political process (see, e.g., Verbrugge \& Jette, 1994). The most common definition of universalism would require the theoretical and practical applicability to all members of one kind (Stefánsson, 2012). However, "disabled people" or "people with disabilities" are overarching categories of diverse groups that reflect the relationality and context-dependence of disability in various institutions and organizations as in society more generally-and throughout the life course (Powell, 2003). Classificatory concepts of kinds of people continuously and sometimes rapidly morph (Hacking, 1999), emphasizing the importance of historical analyses of often ambivalent meanings of dis/ability categories. These are embedded in diverse disability policies and programs, originating in different eras, that reflect often contrary models of disability, from deficit orientation to human rights (see, e.g., Maschke, 2008).

In fact, classical contributions to disability studies emphasize that disability is a universal human condition that affects every human being to a certain degree over their life course (Zola, 1989). Yet, instead of an advancing universalism, institutional arrangements in education and employment do not counteract disablement but have rather been built upon ideas of disability as bodily, mental, and social deviance, with policies oriented to a mythical yet influential notion of the "normal life course" (Powell, 2003; Priestley, 2000). In many contemporary societies, educational inequalities have decreased with regard to access, participation, and attainment, such as in terms of gender (Hadjar \& Becker, 2009). "Normalcy" in adulthood among men was long associated with commodified work (Polanyi, 1944/2001), whereas for women this is increasingly associated with labor force participation along with unpaid reproductive activities (Becker-Schmidt, 2010). However, regarding disability these associations are much more precarious and contradictory since people with a wide variety of perceived impairments and disabilities are often stigmatized and excluded from both productive as well as reproductive activities (Waldschmidt, 2010, p. 49). Unlike other characteristics, continuous growth and differentiation of disability classification has led to a large, highly diverse minority group, to be understood as representing ubiquitous human variation (Schriner \& Scotch, 2001).

Firstly, the massive expansion of education at all levels has made most education systems more inclusive, with compulsory schooling the most universalistic policy in most countries. However, within that increasingly inclusive context, special education serves an ambivalent role: Historically, it ensured participation for many pupils previously entirely excluded from formal education, yet it also accomplished this by diverting pupils with recognized SEN into lower-status and often spatially distinct learning spaces. Special education, especially when it is offered in segregated or separated settings is per se anti-universalistic. Indeed, the existence of such structures calls the inclusivity of the entire educational system into question-in stark contrast to the mandate of the UN Convention on the Rights of People with Disabilities (UN-CRPD), now ratified by almost all countries, but not the United States. The 50 US education systems retain an institutional logic of "separation" with special classes within general schools. The German-speaking countries maintain a logic of "segregation"-evidenced by their ubiquitous segregated special schools-in the Länder of Germany and Austria and in the Swiss Kantone/cantons (see section 3.2). Special facilities or special classes are dependent on the classification of a certain group of pupils as deviant or "abnormal." Paradoxically, this approach, under the guise of widening access to include all children and youth, has historically been associated with an anti-universalistic, targeted distribution of "special" or additional resources (Richardson \& Powell, 2011, p. 76). To be labelled as being a pupil "with SEN" often coincides with the provision of special resources to cover specific identified learning needs beyond the usual provisions of a particular school setting. However, school segregation continues to lead to lower educational achievement and further disadvantage in school-to-work transitions-incompatible with the human right to inclusive education (Blanck, in press; Pfahl, 2011). Thus, this trade-off of being officially classified and labeled to get special resources has been called a "resource-labeling-dilemma" (Füssel \& Kretschmann, 1993). However, theories claim that this dilemma may be mitigated by the universalization of the provisions to entire inclusive learning groups or schools. Such universal provision requires considerable, sustained resources. Yet even among highly inclusive Nordic societies there are differences, with Iceland and Finland having high classification rates, whereas Sweden avoids specific SEN categories (Powell, 2011/2016).

Secondly, the dimension of social protection in adulthood mirrors this educational dilemma. Disability benefits for young adults are also per se anti-universalistic and selective because in modern capitalist states "normal" adulthood is associated with a work-based distribution system. The allocation into a need-based distribution system is dependent on the medical-legal classification of a certain group, which is provided by the validation device of the societal knowledge about individuals (Stone, 1984, p. 21). The welfare state intertwines this medical-legal classification with a special resource allocation system (Tschanz, 2015). "Disability" has the function of a "categorial resolution," as individuals are classified as deviant from the norm within a work-based distribution system and provided with access in a need-based distribution system to compensate their recognized needs (Stone, 1984, 
p. 21). This dilemma could be mitigated by the recognition of the needs of the whole population and the recognition of disability as a universal human condition (Zola, 1989). Such universal recognition would require a considerable change in the culture-specific perception of "normalcy" and a "normal life course." Flexibilization would allow for more permeable understandings of all human beings as inherently fragile and needy beings whose capabilities and needs change over the life course. Such an approach would prevent the perception of disabled people as being different, and having their collective needs pitted against other societal groups (Zola, 1989, p. 19).

In social policy research, questions around universalism often target the distribution of provisions to secure a "socially acceptable standard of living independently of market participation" (Esping-Andersen, 1990, p. 37). Yet labor market participation is tenuous for many disabled people, and prevalent exclusion from work comes with huge material disadvantages, reduced social participation, and vilification (Waldschmidt, 2011, p. 71). This is the reason most collective actors representing the interests of disabled people demand sustainable integration in commodified work seen as a precondition to full recognition and citizenry (Waldschmidt, 2011, p. 71). Therefore, for disabled people, alongside the right not to work, the right to engage in paid employment is valuable (Grover \& Piggott, 2015). Ideally, engagement in the world of work has the characteristics of gainful employment (Kronauer, 2018).

However, current liberal democracies with capitalist market economies cannot provide universalistic answers in absolute terms to both of these rights. As Dahrendorf (2000, p. 1067) argues, an individual's freedom not to work is an important liberal principle. Only authoritarian regimes execute(d) policies of forced and compulsory labor. Western liberal democracies have rather built welfare states that provide some degree of de-commodification (Esping-Andersen, 1990). On the other hand, the universal right to gainful employment is something liberalism cannot enforce (Dahrendorf, 2000, p. 1067). Inherent to the process of selling people's labor as a "fictitious commodity" (Polanyi, 1944/2001), there is a cleavage between the societal goal of inclusion and the employer's freedom to select the most "productive" workers (Nadai \& Canonica, 2019). Liberalism cannot enforce the universality of the former because it attaches remarkable importance to the latter. However, some liberal democracies have placed the other right-freedom not to work-under serious threat due to a new form of authoritarianism consisting of rigid workfare policies and a relentless hunt for cases of welfare fraud, making tighter control measures inevitable (Dahrendorf, 2000, p. 1067). Classification provides access to some options for negotiating the world of work; however, less so in work than in education can the state aim for universalistic policies and programs (Maschke, 2008). Examining the contrasting institutional logics regarding education and work helps understand why.

\subsection{Neo-Institutionalism, Logics, and Inter-Institutional Coordination of Education and Work}

Institutions are "stable designs for chronically repeated activity sequences" (Jepperson, 1991, p. 145). These designs come in various forms, and social life unfolds within them following various logics. Thornton and Ocasio (2008, p. 101) define institutional logics as "socially constructed, historical patterns of material practices, assumptions, values, beliefs, and rules by which individuals produce and reproduce their material subsistence, organize time and space, and provide meaning to their social reality." This institutional logic approach focuses on the consequences of institutional characteristics in shaping organizations and the individuals acting in them, accordingly; conversely, individuals and organizational actors also participate in evolving institutional logics-linking institutions and action as well as structures and processes (Thornton \& Ocasio, 2008, p. 100). Conceptualizing such logics, Friedland and Alford (1991) emphasize that the bureaucratic state, the capitalist market, and democracy are key institutional sectors, each with its own distinct logic, that operate together as an inter-institutional system.

The existence of contrasting institutional logics and institutionalized organizations fundamentally challenges universal social policies, visible especially at interinstitutional transition points, such as young adults' school-to-work transitions. Policies like compulsory schooling or social assistance exist in many countries (World Bank, 2019). Usually policies focus on one stage of life, with few, such as job coaching (Pfahl, 2011) and employment counseling (Blanck, in press), facilitating interaction or supporting individuals in transitioning between life course phases. If institutions of education and work exhibit important similarities relating to dis/ability, they also have significant differences in their logics, which, we argue, result in their (lack of) interinstitutional coordination.

The institutional logics of schooling and employment are ideationally driven by conceptions of achievement and performance. However, whereas the aim of schooling is to foster and compensate via learning opportunities to develop knowledge and skills, employment support is provided to enable individuals to apply their knowledge and skills to achieve certain tasks. In the normative dimension, the values and orientations of professions in determining goals and relevant activities but also in adjudicating who may provide appropriate support-whether in schools, employment agencies, or in firms-exemplifies an overarching logic across institutions. Finally, in the regulative dimension, the logic is one of additional resources and specialized assistance to access the curriculum or the world of work.

Having explicated conceptions of institutional logics, we now address various ideal-typical dimensions of the institutions of education (schooling) and work, comparing Switzerland and the United States. Following 
DiMaggio and Powell (1983) and Scott (2013), we analyze institutionalization processes that reflect ideas (culturalcognitive), standards (normative) and policy (regulative) mechanisms that drive reproduction and change. Each of these dimensions suggests a different rationale for legitimacy, either by virtue of being legally sanctioned (regulative), morally governed (normative), or culturally supported (cognitive). In the cultural-cognitive dimension, we can identify the ideal in both institutions as achievement (performance), the expectation held for individuals (more or less meritocratically). Aligned with this is the dis/ability paradigm, extending across institutional boundaries of education and work: a mythical binary suggesting "normality" - whether as an idealized pupil or worker - that could be contrasted with supposed "abnormality." Whose performances and achievements suffice and whose do not is, however, context-dependent.

The highly problematic notion of ab/normality has been unmasked and critiqued for decades; it is an important strand of work within disability studies (see, e.g., Davis, 1997). Specifically, in terms of classification and categories applied to defining human "kinds" (Hacking, 1999) a range of clinical and legal concepts exists. These demonstrate contrasting institutional logics: Whereas in education (besondere pädagogische Bedürfnisse/besoins éducatifs spécifiques) are defined mainly in medical, psychological, and educational terms, in work the main category is a binary defined in medical and legal terms of "un/employability" (Invalidität/invalidité). For such categories of "abnormal" people, over centuries, professions have established expert claims and organizations have developed to address, serve, and control these groups. Often, being considered "abnormal" due to cumulative disadvantages has led to segregation in special schools, workhouses or asylums (Richardson \& Powell, 2011).

Despite recent emphasis on lifelong learning, the focus of education remains on schooling in childhood and up to young adulthood, with compulsory schooling lasting through the teenage years, followed by vocational education and postsecondary education. The world of work dominates adulthood, ideal-typically stretching from a person's twenties to their sixties and beyond. Compulsory schooling has become a fully universal policy in most societies (Boli et al., 1985), yet special education diffused everywhere increasingly over the past century to ensure that pupils with recognized impairments, disabilities, and illnesses could take part to varying degrees, in publicly-provided schooling (Powell, 2011/2016). The target groups for employment policies are largely demand-driven, depending on sector, occupation, and local labor market conditions. Expectations of employment have become more inclusive of persons with disabilities previously excluded, also due to the effective universalization of schooling that conveyed certificates based on their participation and achievement. Despite higher qualification levels as a group, disabled people attain less education relative to other groups.
For disabled people who routinely face tenuous commitments to their equalized opportunities, a society's collectivist or individualistic direction bears significantly on forms and rates of participation (see Richardson \& Powell, 2011, Chapter 4). Nevertheless, in the dimension of resource provision-whether expectations or responsibilities-states and families provide (more or less) support and inputs to ensure the provision of learning opportunities. By contrast, in employment, it is individuals who are expected to contribute to the production of products and services (outputs). Turning to the organizational forms, there are diverse kinds of schools and more or less inclusive classrooms in education as well as diverse firms and state-financed organizations - such as sheltered workshops-in employment sectors.

Finally, in the regulative dimension, in governance, states vary in their de/centralization, in turn determining how much autonomy school systems and individual schools have to address the challenge of inclusion given local conditions. Labor markets, too, differ considerably, evident in varieties of capitalism, social policy provisions, and political economies (Ebbinghaus \& Manow, 2001; Hall \& Soskice, 2001). In regulatory terms, the state assumes first-order functions of control and funding of schooling, including the accreditation and hiring and firing of teachers in public schools, but has second-order functions in employment, such as quota regulations. Thus, across the different dimensions of institutions-cultural-cognitive, normative, and regulative-important similarities and differences exist between schooling and work (see Table 1).

\subsection{Challenges and Opportunities during Transitions from School-to-Work}

Transitions from educational settings to labor markets can principally take three paths. Firstly, there is the possibility of a transition directly into that segment of the labor market completely governed by market forces in the form of a sustainable integration in commodified work (Waldschmidt, 2011, pp. 69-71). Such a transition requires pupils who have been (comprehensively) empowered by the educational system to function and be competitive within markets reflecting an employment logic. Here the idea of individual performance and expectations held for individuals (more or less meritocratically) can be directly transformed from education to the myriad of firms and other work organizations. Culturalcognitively, stigmatizing labels of ab/normality must be avoided, since meta-analyses indicate that participation in inclusive education increases the likelihood of labor market integration compared to special education (EASNIE, 2018). In the normative dimension, resource provision could be resolved and the "resource-labelingdilemma" in education mitigated by universalizing adequate resource provision to entire learning groups or schools-resolving the need to identify "abnormality," with numerous (un)intended consequences. In the regu- 
Table 1. Institutional dimensions of education and work.

\begin{tabular}{lll}
\hline & Education (schooling) & Work \\
\hline
\end{tabular}

\section{Cultural-cognitive dimension}

Ideal (expectation of individuals)

Dis/ability paradigm

Classification system (categories)

\section{Normative dimension}

Life stage

Target group

Resources: expectations, responsibility

Organizational form(s)

Regulative dimension

Governance

Regulation (state)

\author{
Achievement (performance) \\ Individual deficit versus "normality" \\ Pedagogical, psychological, medical; \\ "special educational needs" \\ medical-legal; \\ "un/employability"
}

childhood; youth (often extended

to 18,21 or 25 years of age)

adulthood

(compulsory schooling)

state provides resources (inputs)

supporting learning opportunities of individuals

diverse school types (classrooms) demand-driven (depends on sector, occupation, local labor market conditions)

individuals contribute to the production of products and services (outputs)

diverse firms and state-financed organizations state

(variance: de/centralized)

first-order function

(control \& funding) market

(types of labor market)

second-order function

(e.g., quota regulations) lative dimension, universalizing such transitions requires the possibility to legally sanction individuals or firms who try to negate the idea of individual performance differences or discriminate against those who do not manage to sufficiently react to market demands.

Secondly, transitions are possible into organizations having characteristics of a quasi-commodification (Waldschmidt, 2011, p. 69), allowing labor market uptake of those unable to compete within pure markets due to functional limitations or impairments-or because of mismatch between employer expectations and youth qualifications. However, such quasi-markets may solidify lacking competencies due to special programs that are often stigmatizing. Here the interconnected principles of individual learning opportunities, expectations, and school performance are not transferable to employment, evident in mostly failed bureaucratic attempts to provide effective transition support (Blanck, in press; Pfahl, 2011). Rather, the powerful norms stemming from deficit-oriented, within-individual models of disability that view disabled people as "abnormal," even "incompetent" (see Jenkins, 1998) is transferred into labor markets. This occurs simultaneously with ongoing education expansion, which paradoxically stigmatizes less-educated youth more than ever (Solga, 2005). Sheltered workplaces are characterized by irrefutable ambivalences, since they enable access to some employment for those not considered competitive in the primary labor market, while they also segregate, with negative effects on participants' educational levels, social networks, income levels, and social prestige (Hassler, 2017). In the regulative dimension, employers are legally sanctioned if they do not fulfill their obligations to recruit and employ disabled employees (given quota regulations). Often, then, financial penalties are partly used to finance quasi-commodification in support programs and employment beyond the primary labor market.

Thirdly, pathways exist in the realm of coordinated market economies that support gradual and stepwise labor market integration. Such bridges often integrate VET programs that are hybrids, containing elements of both education and employment institutions and providing platforms for continuous (re)negotiation between institutional logics of education and work. Busemeyer and Trampusch (2012) emphasize that the political economy of (vocational) education systems mirrors the overall political economy of labor markets. A stepwise labor market integration enables successful transitioning to commodified work of youth as it ideally enhances the match between employer expectations and youth qualifications and facilitates accumulation of formalized skills and employment experiences in early adulthood. In the regula- 
tive dimension, such a transition requires sophisticated inter-institutional coordination in the governance of education and labor market institutions.

In sum, institutionalized differences in how and when youth transition affect their learning opportunities and their experience levels, and interest development throughout their careers. In transitioning' between the institutional spheres of education and work, individuals must be flexible, managing conflicting demands that derive from the above-delineated contrasting institutional logics. Grounding the relational conceptions and contingent classification processes of dis/ability and their consequences with empirical material, we turn now to the contrasting case studies: United States and Switzerland.

\section{Case Studies of Inter-Institutional Coordination and Paradoxical Universalism}

\subsection{United States}

Learning opportunities and skill formation have become increasingly valued public goods, relied on for social and economic development as well as for democratic governance. While compulsory attendance affirmed the goal of participation of all school-age children, it also specified the rules for the exemption of those deemed "ineducable" or "disabled": Developments in special education reflect changes in these rules of access to, and passage through, schooling over a century of decreasing exclusion from public provision of learning opportunities (Richardson \& Powell, 2011). As the emergent mass educational system in the United States reflected heightened standards for education and evolving conceptions of citizenship, the rise of special education changed the dialectical relationships between in/educability, ab/normality, and dis/ability. Over many decades, special educators elaborated their profession, specializing on types of student dis/ability most often based on statistically derived and psychometric definitions of ab/normality and intelligence. From the beginning, such cultural ideologies and models, inscribed in educational policies, affected which children were classified disabled and schooled in mostly segregated special education, if at all. The spread of special education, gradually at first, resulted in the concomitant establishment of special classes and schools to meet these newly acknowledged needs and rights of disabled and disadvantaged students; however, the emphasis in recent decades has been on a continuum of settings, with the majority of students with SEN spending some part of the school day in a special classroom, but nearly all students attend regular schools, thus reflecting an institutional logic of "separation" (Powell, 2011/2016).

When accomplished in practice, compulsory schooling of all children greatly increased student body diversity, as girls, children of low socioeconomic status, migrants and ethnic minorities, and finally those with perceived impairments entered formal schooling. Educational systems responded to this challenge of in- creasing differentiation through school structures, such as age grading and special education. The goal of these reforms was to homogenize learning groups, attempting to resolve tensions between expanded access to common schooling and organizational constraints (Richardson \& Powell, 2011). Rising expectations and standards have led to increasing proportions of students who participate in special education programs. Socializing and integrating diverse student populations continue as crucial challenges facing schools, since the 1970s including all children and youth with disabilities, although the United States has not ratified the UN-CRPD (Powell, 2011/2016).

Examining transitions, analyses of instructional, interpersonal, and institutional processes confirm that placement in higher-level ability groups accelerates achievement growth, whereas placement in lower-level ability groups has the opposite effect. A National Research Council review concluded that students are indeed worse off in low tracks: "The most common reasons for this disadvantage are the failure to provide students in low-track classes with high-quality curriculum and instruction and the failure to convey high expectations for such students' academic performance" (Heubert \& Hauser, 1999, p. 102). Such questions as to the interactions between individual dis/ability, effort, and educational environments and their impact on transitions were pursued in successive waves of the US National Longitudinal Transition Studies (commonly known as the NLTS; see Wagner, Newman, Cameto, Levine, \& Garza, 2006). Crucially, these studies chart accumulation of disadvantages over entire careers and show the impact of disablement on personal, social, and economic outcomes as youth transition from adolescence to adulthood (Wells, Sandefur, \& Hogan, 2003). Funded by the US Department of Education, these important studies document the experiences of a national sample (youth between 13-16 years of age in 2000) as they transitioned, reaching 21-25 years of age in 2009. Key findings show that postsecondary education participation by youth with disabilities more than doubled over time, increasing to nearly a third of youth out of high school up to two years and who had enrolled in a 2- or 4-year college or a postsecondary vocational, technical, or business school (Wagner, Newman, Cameto, \& Levine, 2005). Increasing educational attainment has lifted occupational options and earnings. Beyond the negative effect on postsecondary education participation, differences between disabled youth who did and did not complete high school emphasize that dropouts did not share in the improvements in earnings relative to the federal minimum wage and the shifts in the types of jobs held (i.e., declines in maintenance and clerical jobs, increase in retail jobs) by those who completed high school (Wagner et al., 2005).

While educational attainment is no guarantee of later labor market integration, certification is a precondition, also among disadvantaged and disabled youth. Analyzing student, family, and school factors as predic- 
tors of employment after leaving high school, Carter, Austin, and Trainor (2012) emphasize that employment success is correlated with having held a paid, communitybased job while still in high school and that having independent self-care skills, higher social skills, more household responsibilities, and higher parent expectations increases the odds of labor market integration. Detailed investigations of the types of support provisions and programs offered in secondary schools to improve vocational preparation as well as provided adult services and local labor market conditions are crucial, because the goals of individualized support for accessing the curriculum and for transitioning to vocational training, postsecondary education, and employment are not always met. Labor market exclusion and precarity are less buffered given the limited welfare state, despite the fact that disability was institutionalized as an integral part of national and state policies and social provisions (Skocpol, 1995). Simultaneously, architectural barriers have been removed and unemployment rates have declined. Yet since the Great Recession (2007-2009), work conditions and stress on social systems had particularly negative effects on people with disabilities - and those affected by job loss, itself a source of chronic illness and disability (Kalleberg \& von Wachter, 2017; see also O’Brien, 2013).

In sum, despite increasing participation and attainment rates as well as diverse support programs, disabled youth remain disadvantaged as they attempt to transition. The more active disabled young adults are while in school, the more likely they are to remain integrated in labor markets after graduation. However, supports provided are often insufficient or not individualized enough to ensure successful transitions. Our second case, Switzerland, has an education system structured differently, with an advanced VET system, and a similarly liberal labor market with few protections for most workers.

\subsection{Switzerland}

Schooling in Switzerland, compulsory since 1874, universalized access, also for children understood to have SEN (Wolfisberg, 2002, pp. 61-68). Yet Swiss special educational history is ambivalent, conflicting, and partly injust, evident in segregated organizations (Wolfisberg, 2002). Even today special education retains the institutional logic of segregation, despite the demands of the Federal Disability Equality Law (Behindertengleichstellungsgesetz/Loi sur l'égalité pour les handicapés) and UN-CRPD for universal inclusive education across the life course. Few cantons follow this principle and achieve inclusion, remaining unreprimanded by federal jurisdiction (Kurt \& Heinzmann, 2018). For years, gradually increasing, inclusively schooled populations were not accompanied by decreases in the segregatively schooled population: Advancing inclusive schooling has been accompanied by rising classification rates (Bless \& Kronig, 2000). Recently, the segregation rate has fallen from above $5 \%$ of all pupils (Swiss mean in 2000) to below 3.5\% (Swiss mean in 2016), yet with considerable inter-cantonal disparities (Mejeh \& Powell, 2018, pp. 423-424).

Switzerland is well-known worldwide for its "dual" VET system, in which more than two-thirds of each cohort participates. After compulsory schooling, pupils follow a firm-based training program, accompanied by a school-based component of one to two days per week (Bonvin \& Dahmen, 2017, p. 282). These programs are governed by public and private actors (Bonvin \& Dahmen, 2017; di Maio, Graf, \& Wilson, 2019). Switzerland is a strong collective skill system (Busemeyer \& Trampusch, 2012). A third duality is the interplay and tension between economic and social goals (di Maio et al., 2019). For disabled youth, training conditions can be adjusted by the recognition and compensation mechanism Nachteilsausgleich/compensation des inégalités (Schellenberg, Studer, \& Hofmann, 2016, p. 487). For some youth with impairments or functional limitations, a short-track apprenticeship (Eidgenössisches Berufsattest/attestation fédérale de formation professionnelle) is an important alternative, taking two rather than the usual three to four years of training (Schellenberg et al., 2016, pp. 487-488). Another option is practical education (INSOS PrA/INSOS FPra), not part of official education systems but standardized by INSOS, the syndicate of disability care institutions (Schellenberg et al., 2016, p. 488).

Since 1960, Switzerland has disability insurance (Invalidenversicherung/assurance-invalidité) that is federally governed (see Fracheboud, 2015). Disability insurance is formally universal, providing access to all registered workers or residents after one year, including children and youth. However, selectivity typical for disability insurance schemes is present, with only officially classified children and youth eligible for this support.

Comparing employment rates of people with disabilities, Switzerland's rate is higher (around 55\%) than in the United States (below 40\%), although both lie considerably under general employment rates (OECD, 2010, p. 51). Switzerland's higher rate may be attributed to some extent to the VET system, which enables more robust means of integrating disabled young people into labor markets as it smooths transitions and counteracts supply-demand mismatches. Generally, research shows clear associations of strong VET programs with prevention of youth unemployment (Kriesi \& Schweri, 2019, pp. 58-59). Compared to the United States, problems of inter-institutional coordination are targeted more comprehensively, whereas distributive dilemmas resulting in paradoxical universalism remain endemic.

Firstly, while disability insurance is governed by the Swiss confederation and upper secondary education is governed jointly by the Swiss confederation and cantons (with business interest organizations, private companies and trade unions for VET), primary education and lower secondary education are governed entirely by the cantons. Cantonal education policies are certainly not univer- 
sally inclusive, with persistent inter-cantonal disparities ranging from high segregation rates (special schooling) to more inclusive schooling, mainly at primary level (Mejeh \& Powell, 2018). Attempts to foster transitions are hindered by stigmatizing notions of ab/normality and its (un)intended negative consequences due to institutionalized cantonal special education organizations. Research demonstrates that inclusively schooled pupils more successfully access the labor market (Eckhart, Haeberlin, Sahli Lozano, \& Blanc, 2011). Seen from this perspective, segregated schooling in cantons negatively affects employment. Enhanced inter-institutional coordination between disability insurance and upper secondary education with cantonal (special) education schemes would be necessary. Federally, the disability insurance could play an important role in this process. With a bundle of new policies (Weiterentwicklung der IV/développement continu de l'Al) the Swiss disability insurance currently plans to improve inter-institutional coordination for eligible persons between 13 to 25 years of age, supporting first vocational training opportunities (Lüthi, 2017, p. 17). The expansion of case management support, educational bridging offers and access to private employment agencies, and temporary recruitment services are under way (Lüthi, 2017. p. 17). A bundle of policies exists: employment counselling, job coaching services, opportunities for re-education, job placement services, work trials, daily allowances for youth in a short-track apprenticeship in the primary labor market, and wage subsidies as incentives for employers (Lüthi, 2017, p. 17). Paradoxically, while the insurance program focuses strongly on labor market integration, its classifying of individuals as "invalid" (invalid/invalide) is associated with stigmatization, an explicit category of "abnormality" originating in the 18th century (Stone, 1984; Tschanz, 2015).

Secondly, Swiss VET governance is among the most liberal among coordinated market economies. Business interest organizations and private companies have strong bargaining power in formulating teaching contents and an essential say in VET (Bonvin \& Dahmen, 2017). While school-to-work transitions are generally eased via the vaunted Swiss VET system that supports the majority of youth to adjust as expectations and performances shift from education to employment, the principle of getting an apprenticeship follows mainly market-based selection procedures (Dahmen, Bonvin, \& Beuret, 2017), suboptimally adjusted to the needs of minority groups (Imdorf, 2005). For instance, in contrast to Denmark's and Germany's short-track apprenticeships, Switzerland puts more emphasis on economic efficiency rather than social equality (di Maio et al., 2019). Unlike other countries, Switzerland does not provide a "Youth Guarantee" with a universal right to an apprenticeship or training opportunity, instead following a market-based allocation model (Dahmen et al., 2017, p. 156). Exceptions include youth with certain medical-psychological classification because in these cases the disability insurance is obliged to guarantee the first vocational training opportunity (Lüthi, 2017, p. 17). Paradoxically, while overall inter-institutional coordination works very well for youth who succeed in the market-based selection procedure, youth with impairments or functional limitations are dependent on antiuniversalistic medical-psychological classification to approximate the universal Youth Guarantee.

Thirdly, Switzerland reformed disability insurance over the last 20 years thrice (Probst, Tabin, \& Courvoisier, 2015). While the right to gainful employment has not been codified since Switzerland lacks legal obligations imposed on employers - there is neither an employment quota nor strict anti-discrimination legislation (Nadai \& Canonica, 2019, p. 89; Nadai, Gonon, \& Rotzetter, 2018, p. 407)-these reforms rely on the belief that the medical profession is capable of drawing objective boundaries between deserving people with impairments or illnesses and undeserving applicants; emphasizing tightened medical assessments (Caduff \& Budowski, 2012, pp. 76-79). Furthermore, the recent discourse constructs disablement as a motivational problem justifying the introduction of tighter control mechanisms, which reinforce societal hierarchies based on assumed capabilities (Piecek, Tabin, Perrin, \& Probst, 2019). Therefore, recent developments for adults have increased the legal sanctioning of those individuals who cannot or will not, for whatever reason, work. This danger simultaneously exists for prospective transition policies. In other areas of contemporary Swiss youth policies, a direction best described as "educationfare" arises (Dahmen et al., 2017, p. 155). This neologism, inspired by the term "workfare," means the establishment of stronger welfare conditionality criteria for youth in conjunction with targeting their integration into apprenticeships or other educational settings (Dahmen et al., 2017, p. 155). Therefore, the right to be accompanied by inter-institutional coordination on pathways into the labor market is thwarted by ever-earlier expectations of successful individual performance and outputs. Facilitated inter-institutional coordination via VET and the Swiss disability insurance will have to be critically examined regarding its possible paradoxical consequences for the right not to work.

In sum, contrary to the United States, the main challenge in Switzerland is not activation prior to leaving the education system, since its dual VET system (hardly reproduceable in the United States) provides multiple institutionalized pathways to formalized skills and employment experiences. However, the market-based allocation procedure to access such pathways continues to disadvantage some disabled youth, precluding universal access to VET and the (primary) labor market. For many, their life chances are determined by ambivalent effects of categorical membership (acquired during their cantonal school careers) and the requirements of individual performance and outputs of a liberal labor market. Or they are confronted by the paradox that one has to obtain the former in order to get access to support programs smoothing the pathway to the latter. 


\section{Conclusion}

In our comparative case studies (Ragin, 1992), we linked ideas and evidence with theoretically structured descriptions. In particular, we outlined the school-towork transitions of disabled youth in the United States and Switzerland from an institutional logics perspective. We considered the paradoxical "universalism" that affects contemporary education and disability policy. Both countries constructed a dialectical relationship between in/educability, ab/normality, and dis/ability with the establishment of compulsory universal schooling. This, the most crucial universal policy early in the life course, determines life chances to an increasingly large degree in "schooled societies" (Baker, 2014). This field remains especially challenging because these core institutions are characterized by different institutional logics and complex arrangements of institutionalized organizations, whether stigmatizing special classes (United States) or schools (Switzerland), and the lack (United States) or presence (Switzerland) of VET as a formal bridge between schooling and labor markets that demands coordination and must adjudicate the competing principles of social integration and efficiency.

In both countries, the logic of investment in human capital via years of schooling is matched by enforcement of the logic of performance of paid employment and individual adaptation to labor market conditions. We contrasted their institutional arrangements to support disabled youth transitioning. Especially in transition processes, the interrelation between education and social policies and between families and school and firm environments must be considered. While in the United States, the lack of inter-institutional coordination in the transition phase follows its liberal approach vis-à-vis limited state governance of markets, Switzerland, as a coordinated market economy, provides more transition opportunities via its VET system and has extended social policy insurance, which also supports transitions of classified youth. However, Switzerland does not fully coordinate education and employment systems to ensure successful transitions, also due to its market-based allocation of apprenticeships. Additional and intensified coordination between social policies and employment is partially counteracted by Swiss disability insurance's classification demands, creating a support-labeling-dilemma.

In Switzerland and the US, education and labor market institutions have institutionalized deficit-oriented conceptions of disability, with no paradigm shift towards socio-political, minority or human rights-based models. Both remain strongly oriented towards the ideal of individual performance, whether schooling (learning progress) or paid employment (task accomplishment). The necessity to provide universal opportunities, following the human right to inclusive education or right to work codified in the UN-CRPD, demands such a paradigm shift. This may be coupled with critical assessments of dominant ideas and values surrounding "ab/normality."

\section{Acknowledgments}

We gratefully acknowledge helpful comments on early drafts received from Robin Samuel and three anonymous reviewers. Christoph Tschanz acknowledges the Swiss National Science Foundation (SNSF) for his Doc.CH grant (No. 172008), and both authors thank the SNSF for providing funding to publish this article open access.

\section{Conflict of Interests}

The authors declare no conflict of interest.

\section{References}

Aldrich, H. E., \& Ruef, M. (2006). Organizations evolving (2nd ed.). London: Sage.

Anttonen, A., \& Sipilä, J. (2014). Varieties of universalism. Geneva: United Nations Research Institute for Social Development.

Baker, D. (2014). The schooled society: The educational transformation of global culture. Stanford, CA: Stanford University Press.

Becker-Schmidt, R. (2010). Doppelte Vergesellschaftung von Frauen [The double socialization of women]. In R. Becker \& B. Kortendiek (Eds.), Handbuch Frauen- und Geschlechterforschung [Handbook on women and gender research] (3rd ed., pp. 65-74). Wiesbaden: Springer.

Blanck, J. M. (in press). Übergänge nach der Schule als "zweite Chance"? [Post-school transitions as a "second chance"]. Weinheim: Beltz Juventa.

Bless, G., \& Kronig, W. (2000). Im Schatten der Integrationsbemühungen steigt die Zahl der Sonderklassenschüler stetig an [In the shadow of intregration attempts, the number of pupils in special classes rises]. Schweizer Schule, 87, 3-12.

Boli, J., Ramirez, F. O., \& Meyer, J. W. (1985). Explaining the origins and expansion of mass education. Comparative Education Review, 29(2), 145-170.

Bonvin, J.-M., \& Dahmen, S. (2017). The Swiss welfare state system: With special reference to education policy. In C. Aspalter (Ed.), The Routledge international handbook to welfare state systems (pp. 274-290). London: Routledge.

Busemeyer, M. R., \& Trampusch, C. (Eds.). (2012). The political economy of collective skill formation. Oxford: Oxford University Press.

Caduff, P., \& Budowski, M. (2012). "Scheininvalide"? Zum Problem der Grenzziehung zwischen legitimen und "illegitimen" Krankheitsbildern ["Invalidpretenders?" On the problem of the boundary drawn between legitimate and "illegitimate" medical conditions]. In M. Budowski, M. Nollert, \& C. Young (Eds.), Delinquenz und Bestrafung [Delinquency and penalization] (pp. 62-82). Zurich: Seismo.

Carter, E. W., Austin, D., \& Trainor, A. A. (2012). Predictors of postschool employment outcomes for young 
adults with severe disabilities. Journal of Disability Policy Studies, 23(1), 50-63.

Dahmen, S., Bonvin, J.-M., \& Beuret, B. (2017). The dynamics of youth policies in Switzerland: Between participation and activation. In H.-U. Otto, V. Egdell, J.-M. Bonvin, \& R. Atzmüller (Eds.), Empowering young people in disempowering times (pp. 144-159). Cheltenham: Edward Elgar.

Dahrendorf, R. (2000). Die globale Klasse und die neue Ungleichheit [The global class and the new social inequality]. Merkur, 54(619), 1057-1068.

Davis, L. J. (1997). Constructing normalcy. In L. J. Davis (Ed.), The disability studies reader (pp. 9-28). London: Routledge.

DiMaggio, P. J., \& Powell, W. W. (1983). The iron cage revisited: Institutional isomorphism and collective rationality in organizational fields. American Sociological Review, 48, 147-160.

di Maio, G., Graf, L., \& Wilson, A. (2019). Torn between economic efficiency and social equality? Short-track apprenticeships in Denmark, Germany and Switzerland. European Educational Research Journal, 18(6), 699-723.

EASNIE. (2018). Evidence of the link between inclusive education and social inclusion. Odense: European Agency for Special Needs and Inclusive Education.

Ebbinghaus, B., \& Manow, P. (Eds.). (2001). Comparing welfare capitalism. London: Routledge.

Eckhart, M., Haeberlin, U., Sahli Lozano, C., \& Blanc, P. (2011). Langzeitwirkungen der schulischen Integration [Long-term effects of school integration]. Berne: Haupt.

Esping-Andersen, G. (1990). The three worlds of welfare capitalism. Cambridge: Polity Press.

Fracheboud, V. (2015). L'introduction de l'assurance invalidité en Suisse (1944-1960) [The introduction of the disability insurance in Switzerland (1944-1960)]. Lausanne: Antipodes.

Friedland, R., \& Alford, R. A. (1991). Bringing society back in: Symbols, practices and institutional contradictions. In W. W. Powell \& P. J. DiMaggio (Eds.), The new institutionalism in organizational analysis (pp. 232-263). Chicago, IL: University of Chicago Press.

Füssel, H.-P., \& Kretschmann, R. (1993). Gemeinsamer Unterricht für behinderte und nichtbehinderte Kinder [Joint instruction for disabled and nondisabled children]. Witterschlick: Wehle.

Gomolla, M., \& Radtke, F. O. (2002). Institutionelle Diskriminierung [Institutional discrimination]. Opladen: Leske \& Budrich.

Grover, C., \& Piggott, L. (2015). A right not to work and disabled people. In C. Grover \& L. Piggott (Eds.), Disabled people, work and welfare (pp. 239-255). Bristol: Policy Press.

Haber, M. G., Mazzotti, V. L., Mustian, A. L., Rowe, D. A., Bartholomew, A. L., Test, D. W., \& Fowler, C. H. (2016). What works, when, for whom, and with whom: A meta-analytic review of predictors of postsecondary success for students with disabilities. Review of Educational Research, 86(1), 123-162.

Hacking, I. (1999). The social construction of what? Cambridge, MA: Harvard University Press.

Hadjar, A., \& Becker, R. (Eds.). (2009). Expected and unexpected consequences of the educational expansion in Europe and the USA. Berne: Haupt.

Hall, P. A., \& Soskice, D. (Eds.). (2001). Varieties of capitalism. Oxford: Oxford University Press.

Halvorsen, R., \& Hvinden, B. (2018). Youth, diversity and employment in times of crisis and economic restructuring: An introduction. In R. Halvorsen \& B. Hvinden (Eds.), Youth, diversity and employment (pp. 1-31). Cheltenham: Edward Elgar.

Hassler, B. (2017). Geschützte Arbeitsplätze und Eingliederungsmanagement [Sheltered workshops and integration management]. In T. Geisen \& P. Mösch (Eds.), Praxishandbuch Eingliederungsmanagement [Handbook of integration management in praxis] (pp. 1-13). Wiesbaden: Springer.

Heidenheimer, A. J. (1997). Disparate ladders: Why school policies differ in Germany, Japan, and Switzerland. New Brunswick, NJ: Transaction Publishers.

Heubert, J. P., \& Hauser, R. M. (Eds.). (1999). High stakes: Testing for tracking promotion and graduation. Washington, DC: National Academy Press.

Imdorf, C. (2005). Schulqualifikation und Berufsfindung [School qualification and vocational orientation]. Wiesbaden: Springer.

Jenkins, R. (Ed.). (1998). Questions of competence: Culture, classification and intellectual disability. Cambridge: Cambridge University Press.

Jepperson, R. L. (1991). Institutions, institutional effects, and institutionalism. In W. W. Powell \& P. J. DiMaggio (Eds.), The new institutionalism in organizational analysis (pp. 143-163). Chicago, IL: University of Chicago Press.

Kalleberg, A. L., \& von Wachter, T. M. (2017). The U.S. labor market during and after the great recession. RSF, 3(3), 1-19.

Kriesi, I., \& Schweri, J. (2019). Types of education, achievement and labour market integration over the life course. Social Inclusion, 7(3), 58-64.

Kronauer, M. (2018). Gainful employment between inclusion and exclusion In G. Wansing, F. Welti, \& M. Schäfers (Eds.), The right to work for persons with disabilities (pp. 121-134). Baden-Baden: Nomos.

Künzler, D., \& Nollert, M. (2017). Varieties and drivers of social welfare in sub-Saharan Africa. Socialpolicy.ch, 2(2), 1-23.

Kurt, S., \& Heinzmann, A. (2018). Ein Umdenken ist gefordert. Kindeswohl als Argument für die schulische Segregation [Rethinking child well-being as an argument for school segregation]. SozialAktuell, 6, 38-39.

Ludwig-Mayerhofer, W., Pollak, R., Solga, H., Menze, L., Leuze, K., Edelstein, R., . . Kühn, S. (2019). Vocational 
education and training and transitions into the labor market. In H. P. Blossfeld \& H. G. Roßbach (Eds.), Education as a lifelong process (3rd ed.). Wiesbaden: Springer.

Lüthi, A. (2017). Verstärkung der beruflichen Eingliederung [Strengthening vocational integration]. CHSS Soziale Sicherheit, June(2), 15-19.

Marshall, T. H. (1992). Citizenship and social class. London: Pluto Press. (Original work published 1950)

Maschke, M. (2008). Behindertenpolitik in der Europäischen Union [Disability policy in the European Union]. Wiesbaden: Springer.

Mejeh, M., \& Powell, J. J. W. (2018). Inklusive Bildung in der Schweiz-Zwischen globalen Normen und kantonalen Besonderheiten [Inclusive education in Switzerland: Between global norms and cantonal specificities]. Bildung und Erziehung, 71, 412-431.

Nadai, E., \& Canonica, A. (2019). The moralization of labor: Establishing the social responsibility of employers for disabled workers. In S. Schiller-Merkens \& P. Balsiger (Eds.), The contested moralities of markets (pp. 87-106). Bingley: Emerald.

Nadai, E., Gonon, A., \& Rotzetter, F. (2018). Costs, risks and responsibility. Negotiating the value of disabled workers between disability insurance and employers. Swiss Journal of Sociology, 44(3), 405-422.

Neckel, S., \& Sutterlüty, F. (2005). Negative Klassifikationen. Konflikte um die symbolische Ordnung sozialer Ungleichheit [Negative classifications. Conflicts surrounding die symbolic order of social inequality]. In W. Heitmeyer \& P. Imbusch (Eds.), Integrationspotenziale einer modernen Gesellschaft [Integration potentials in contemporary society] (pp. 409-428). Wiesbaden: Springer.

O'Brien, R. L. (2013). Economy and disability: Labor market conditions and the disability of working-age individuals. Social Problems, 60(3), 321-333.

OECD. (2010). Sickness, disability and work: Breaking the barriers. Paris: OECD.

Pfahl, L. (2011). Techniken der Behinderung. Der deutsche Lernbehinderungsdiskurs, die Sonderschule und ihre Auswirkungen auf Bildungsbiografien [Technologies of disability. The German discourse on learning disabilities, the special school and its effects on educational biographies]. Bielefeld: Transcript.

Piecek, M., Tabin, J.-P., Perrin, C., \& Probst, I. (2019). The 'compliant,' the 'pacified' and the 'rebel': Experiences with Swiss disability insurance. Disability \& Society, 34(4), 583-606.

Polanyi, K. (2001). The great transformation. Boston, MA: Beacon Press. (Original work published 1944)

Powell, J. J. W. (2003). Constructing disability and social inequality early in the life course. Disability Studies Quarterly, 23(2), 57-75. Retrieved from http://dsqsds.org/article/view/414/575

Powell, J. J. W. (\{2011\} 2016). Barriers to inclusion: Special education in the United States and Germany. Abingdon: Routledge.
Priestley, M. (2000). Adults only: Disability, social policy and the life course. Journal of Social Policy, 29(3), 421-439.

Probst, I., Tabin, J.-P., \& Courvoisier, N. (2015). De la réparation à la réversibilité. Un nouveau paradigme dans l'assurance invalidité? [From compensation to reversibility. A new paradigm in disability insurance?]. Swiss Journal of Sociology, 41(1), 101-117.

Ragin, C. C. (1992). "Casing" and the process of social inquiry. In C. C. Ragin \& H. S. Becker (Eds.), What is a case? (pp. 217-226). Cambridge: Cambridge University Press.

Richardson, J. G., \& Powell, J. J. W. (2011). Comparing special education: Origins to contemporary paradoxes. Stanford, CA: Stanford University Press.

Schellenberg, C., Studer, M., \& Hofmann, C. (2016). Transition Übergang Schule-Beruf [School-to-work transitions]. In I. Hedderich, G. Biewer, J. Hollenweger, \& R. Markowetz (Eds.), Handbuch Inklusion und Sonderpädagogik [Handbook of inclusion and special education] (pp. 485-490). Bad Heilbrunn: Klinkhardt.

Schriner, K., \& Scotch, R. K. (2001). Disability and institutional change: A human variation perspective on overcoming oppression. Journal of Disability Policy Studies, 12(2), 100-106.

Scott, W. R. (2013). Institutions and organizations (4th ed.). London: Sage.

Skocpol, T. (1995). Social policy in the United States. Princeton, NJ: Princeton University Press.

Solga, H. (2005). Ohne Abschluss in die Bildungsgesellschaft [Without qualification in the education society]. Opladen: Barbara Budrich.

Stefánsson, K. (2012). What is in a word? Universalism, ideology and practice. In A. Anttonen, L. Häikiö, \& K. Stefánsson (Eds.), Welfare state, universalism and diversity (pp. 42-68). Cheltenham: Edward Elgar.

Stone, D. A. (1984). The disabled state. Philadelphia, PA: Temple University Press.

Thornton, P. H., \& Ocasio, W. (2008). Institutional logics. In R. Greenwood, C. Oliver, R. Suddaby, \& K. Sahlin (Eds.), The Sage handbook of organizational institutionalism (pp. 99-129). London: Sage.

Thornton, P. H., Ocasio, W., \& Lounsbury, M. (2012). The institutional logics perspective. Oxford: Oxford University Press.

Tschanz, C. (2015). Die Welten des Aufbaus und Brechens von Barrieren-Europäische Behindertenpolitiken im Vergleich [The worlds of constructing and breaking of barriers-A comparison of European disability policies]. Newsletter Studienbereich Soziologie, Sozialpolitik und Sozialarbeit, 16, 41-54.

Tschanz, C. (2017). Zwischen Barrierefreiheit, Aktivierung und Marktradikalismus: Der Zugang zum Arbeitsmarkt durch die Invalidenversicherung [Between accessibility, activation and market radicalism: Accessing the labor market via disability insurance]. Schweizerische Zeitschrift für Heilpädagogik, 23(3), 27-35. 
Verbrugge, L. M., \& Jette, A. M. (1994). The disablement process. Social Science and Medicine, 38(1), 1-14.

Wagner, M., Newman, L., Cameto, R., \& Levine, P. (2005). Changes over time in the early postschool outcomes of youth with disabilities. Menlo Park, CA: SRI International.

Wagner, M., Newman, L., Cameto, R., Levine, P., \& Garza, N. (2006). An overview of findings from wave 2 of the National Longitudinal Transition Study-2 (NLTS2). Menlo Park, CA: SRI International.

Waldschmidt, A. (2010). Das Mädchen Ashley oder: Intersektionen von Behinderung, Normalität und Geschlecht [Intersections of disabilty, normality, and gender]. In J. Jacob, S. Köbsell, \& E. Wollrad (Eds.), Gendering disability (pp. 35-60). Bielefeld: Transcript.

Waldschmidt, A. (2011). Existenzsicherung-Ein soziales Recht? [The minimum standard of subsistence as a social right?]. In M. Dederich, \& K. Grüber (Eds.), Herausforderungen: Mit schwerer Behinderung leben [Challenges: Living with severe disability] (2nd ed., pp. 61-74). Frankfurt am Main: Mabuse.

Wells, T., Sandefur, G. D., \& Hogan, D. P. (2003). What happens after the high school years among young persons with disabilities? Social Forces, 82(2), 803-832.

Wolfisberg, C. (2002). Heilpädagogik und Eugenik [Special education and eugenics]. Zurich: Chronos.

World Bank. (2019). The atlas of social protection indicators of resilience and equity. Washington, DC: World Bank. Retrieved from http://datatopics.worldbank. org/aspire

Zola, I. K. (1989). Toward the necessary universalizing of a disability policy. The Milbank Quarterly, 67(2), 401-428.

\section{About the Authors}
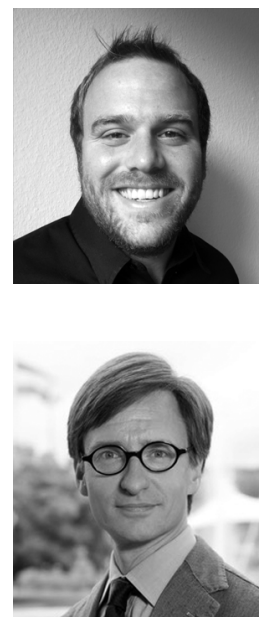

Christoph Tschanz is a PhD candidate at the University of Fribourg, Switzerland, in the Department of Social Work, Social Policy and Global Development, funded by a Doc.CH grant. He specializes in comparative perspectives on European disability policies. Christoph holds a master's degree in Sociology and a bachelor's degree in Special Education and Social Pedagogy, both from the University of Fribourg. He previously worked at the Service für unterstützte Berufsbildung, a specifically VET-oriented supported training and employment program for people with an autism-spectrum condition on behalf of the Swiss disability insurance.

Justin J. W. Powell is Professor of Sociology of Education in the Institute of Education \& Society, University of Luxembourg. His comparative institutional analyses chart persistence and change in special and inclusive education, in vocational training and higher education, and in science systems and research policy. His award-winning books include Barriers to Inclusion: Special Education in the US and Germany (Routledge, 2011/2016), Comparing Special Education: Origins to Contemporary Paradoxes (Stanford University Press, 2011), and The Century of Science: The Global Triumph of the Research University (Emerald, 2017/2019). 